\title{
The idea of a beautiful death in Italian literature of the Great War
}

\author{
Carlo Moll (10 \\ History Faculty, University of Cambridge, Cambridge, UK \\ Email: carlo.moll@cantab.net
}

(Received 5 March 2021; revised 14 June 2021; accepted 20 June 2021)

\begin{abstract}
Through the comparative reading of Italian literature of the Great War (letteratura di guerra) published between 1915 and 1940, it will be shown that both among veterans of the conflict and civilian writers there existed a standardised image of falling 'beautifully' in combat that entailed specific components relating to location, time, final gestures and last invocations, and which aimed to make death in battle more militarily and culturally palatable for Italian audiences. At the same time, the letteratura di guerra presented naturalistic descriptions of the anonymous mass death of peasant soldiers and, thereby, created a pathos of beauty and suffering that made the Italian literature of the Great War prototypical for a new kind of spiritual realism that became one of the mainstreams of cultural expression in Fascist Italy.
\end{abstract}

Keywords: First World War; war literature; fallen soldiers; memory; veterans

\section{Introduction}

Death in battle, and the commemoration of the fallen by the living, has been a topic of consistent interest to historians of the Great War and scholars of war literature, such as Paul Fussell (2000), Jay Winter (1998) or George Mosse (1990). For the Italian case, Mario Isnenghi $(1973,27)$ has described the wish for self-destruction, 'il cupio dissolvi', as a 'costante della letteratura della grande guerra'. More recently, Marco Mondini (2014, 315) has identified self-sacrifice as a recurring, indeed core theme in the Italian letteratura di guerra. On the other hand, Todero $(1999,12)$ has pointed to the experience of dying on the Alpine front as essentially one of anonymity and the violent dissolution of the body into its various pieces, which was in fact, as Stéphane Audoin-Rouzeau and Annette Becker $(2002,39)$ have rightly observed, 'a salient characteristic' of the Great War. Fabio Caffarena $(2013,171)$ has memorably described the front as a 'crazy world', in which 'the senses were over-stimulated by the nauseating smell of decomposing bodies, by the artificial glare of the floodlights, by the flashing and the rumbling of the explosions; all of which lead to devastating, emotional and sensory disturbances'. Both physically and mentally, the overwhelming sight and smell of death at the front was, as Barbara Bracco $(2012,47)$ has remarked, 'un richiamo continuo a un destino per tutti' and a source of great existential dread that was incommunicable to relatives and friends at home. In this

(C) The Author(s), 2021. Published by Cambridge University Press on behalf of the Association for the Study of Modern Italy. This is an Open Access article, distributed under the terms of the Creative Commons Attribution licence (https://creativecommons. $\mathrm{org} /$ licenses/by/4.0/), which permits unrestricted re-use, distribution, and reproduction in any medium, provided the original work is properly cited. 
regard, Wanda Wilcox $(2018,170)$ has shown that overcoming the fear of death (along with the apprehension to kill) and its substitution with the notion of 'sacrifice' was one of the primary goals of military training in prewar Italy, which achieved, however, only mixed results in the psychological accommodation of soldiers to the thought of falling in battle.

While previous studies have thus made valuable contributions to the study of the Italian experience of the war, they have not focused sufficiently on the performative, iconographic quality of the myth of la bella morte presented in the letteratura di guerra, which translated the instinctive fear of a violent death into a more militarily and culturally palatable fear of dying 'wrongly' or dishonourably. As this article will show, Italian authors of war literature expressed remarkably consistent, precise and uniform clichés about what constituted a 'good death' in battle, pertaining to location, occasion, final gestures and invocations, and what did not. There was, in other words, a clear, commonly shared understanding of how, where and when a soldier should ideally fall in battle and how, where and when he should ideally not. In this context, it will further be shown how death replicated social status and the class structure of the Royal Italian Army, assigning a highly personalised and iconographic demise to officers, members of elite units such as the Arditi storm-troops, specialised Alpini mountaineer units, cavalry squadrons or pilots, such as those belonging to Gabriele d'Annunzio's famed Serenissima squadron, whilst usually relegating common soldiers (the proverbial umili fanti) to anonymous and grisly deaths en masse in the trenches or in the ever-contested no-man's-land. ${ }^{1}$ It will further be argued that the concept of la bella morte was a crucial mythopoeic element in the creation of Fascist pathos, complemented by the naturalistic description of the nameless suffering of the peasantry and transforming the letteratura di guerra into an exemplary, spiritual-realistic type of "new national literature' during the interwar period in Italy. ${ }^{2}$

The basis for this article is a selected corpus of Italian war literature or letteratura di guerra consisting of diaries, memoirs, novels and theatre plays, written between 1915 and 1940 by Italian veterans of the Great War. The inclusion of the authors Alfredo Panzini and G.A. Borgese, who did not serve in the Italian Armed Forces, provide a valuable perspective from the home front and show how the idealisation of death on the battlefield was equally shared by civilians and, therefore, not confined to soldiers and veterans. In addition, I have used a broad range of sources relating to the representation of death as a beautiful event in prewar Italian discourses in so-called Interventionist milieus, which will help to subsequently contextualise the prevalence of the idea of la bella morte in the Italian literature of the Great War.

\section{The idea of dying well in Italian cultural discourses before the Great War}

The idea of a beautiful death in battle has deep roots in European culture stretching back to Roman and Greek antiquity, medieval Catholicism and the Renaissance (Edward 2007, 23; Jox et al. 2018, 104-08; Domenichelli 2004, 60; Shinners 1997, 537). In this tradition of commemoration, certain narrative elements, funerary rituals and images from different historical periods have frequently been reused and reinvented in the celebration of fallen soldiers, who were thereby integrated into national histories and cultures of military sacrifice. Jay Winter $(1998,223)$ has argued that, after 1914, 'a complex traditional vocabulary of mourning, derived from romantic, or religious forms, flourished, largely because it helped mediate bereavement', whilst George Mosse $(1990,101)$ has referred to anachronistic representations detectable in war monuments built after the First World War, in which medieval imagery, such as swords, knights and lances, abounded in order to mask the reality of mechanised trench warfare.

A similar argument has recently been put forward by Stefan Goebel (2007), who has argued that a medievalist tradition that had already taken root in the imagination of 
Europeans during the nineteenth century, after 1914-1918, in the commemoration of the Great War, 'was transmuted into a discourse of mourning in an age of industrialised carnage, a discourse recovering the individual soldier who had perished in the anonymous battles of matériel of the machine age' (13-14). Yet whilst the medievalist boom in the commemoration of the Great War represented the re-invocation of historical imagery that had passed through a stage of romanticisation and artistic reinvention, the continuation of prewar discourses surrounding the transient nature of life into the wartime representation of dying in literature, paintings and monuments was frequently much more contemporary and uninterrupted. Thus, Paul Fussell $(2000,282)$ has alluded to the theme of 'beautiful suffering lads' prevalent in English prewar literature, 'for which the war sanctioned an expression more overt than ever before'. Similarly, in Italy, the notion of la bella morte experienced particular popularity in the two decades immediately preceding the outbreak of the Great War, which prepared the subsequent celebration of a quick, sudden death in battle in the Italian letteratura di guerra.

In Gabriele d'Annunzio's best-selling novel Il trionfo della morte (1894), the 'noble manner of dying' is longingly described as that of Percy Shelley on the pyre, akin to the 'ancient heroes of Greece, which an invisible power removed unexpectedly from the earth and carried off transfigured into the Jovian sphere' (d'Annunzio 1897, 332). In the eyes of the poet, death should be performed as a ritualised spectacle for the gods and artistically celebrated as the entry into a nocturnal 'empire of marvels', in which man became part of the 'Great All' (331). D'Annunzio was a central figure in an intellectual scene that fused journalism with artistic expression and nationalistic politics and which cultivated an intense fascination with violence, self-sacrifice, transgression and transcendence in an overall attempt to épater la bourgeoisie in any way possible. As the journalist and modernist editor Giuseppe Prezzolini lamented, in an article for the Florentine journal Leonardo in 1903, Italy's bourgeois classes were not ready to 'rise to the conscience of a true aristocracy and to prefer the beautiful death in battle to slow decay in senility' (Il Sofista 1960, 131). Another widely influential philosophical work from the same era and milieu was published in 1908 and entitled $\mathrm{La}$ rivolta ideale. It had been written by the reclusive Romagnolese philosopher and historian Alfredo Oriani $(1924,264)$, who mused that 'death in war is still the most spiritual, as man succumbs here to the power of an idea in the consciousness of his own will'.

Three years later, in 1911, the notion of a 'beautiful death' in action was framed in a similar quasi-military context in a short story entitled La bella morte by the modernist author Federico de Roberto, in which a young sailor tragically dies in a storm at sea whilst en route to a colonial battle zone. Here, death triumphs over life as an enviable blessing in disguise for the departed:

No, it was not necessary to mourn. He had died as a sailor, at his post, under the eyes of his father, kidnapped by the storm, at the climax of youth, burning with love, dreaming glory, in full enchantment, before awakening: rare fate, enviable death. He had envied him, deafly, a few hours ago, for his fortune; but what disillusionments, what pains, and what horrors had life kept in store for him? For this one had to envy him: that he had disappeared in the great purity of the sea, taking away a vision of beauty and a sense of happiness! (de Roberto 1917, 326)

As Mario Isnenghi has highlighted, it was indeed colonial war literature that prepared the celebration of mechanised warfare in the Alpine trenches of the Great War. In Francesco Tommaso Marinetti's La battaglia di Tripoli, which was published in the same year as De Roberto's La bella morte as the Futurist poet's first-hand account of the Italo-Turkish War, 'la morte è continuamente presente come fatto, mai come problema' and as a 'parte del macabro, dovizioso spettacolo' (Isnenghi 1973, 26-7). 
While the celebration of a beautiful death in battle appears most prominently and sophisticatedly in the literature of the interventionist Italian intelligentsia, it also surfaced in contemporary mass media. On 20 May 1915 - exactly three days before the Italian declaration of war on the Austro-Hungarian Empire - the Milanese daily La Stampa prominently featured a panegyric article, simply captioned La bella morte, on the heroic death of a Serbian officer who had dutifully defended his post almost alone against an overwhelming number of enemy troops and firepower, until he finally found a 'beautiful death' in action and, according to La Stampa, was even honoured by the Austrian army for his grim commitment to holding the line at all costs (Bassi 1915, 3). When Italy finally entered the Great War on the side of the Entente on 24 May 1915, the notion that a death suffered in battle could indeed become a work of art had thus been supplied with a well-established and rich intellectual history, which made it possible, as Cinzia Rita Gaza argued, to transform la bella morte into 'an instrumental cliché so that the relatives, [and] society may comprehend the loss and represent it in an acceptable form' (Rita Gaza 2014, 63).

\section{Bad ways to die on the Alpine front}

On the Italian front, death could come in any number of different ways. A soldier could be mortally wounded trying to cross no-man's-land, by receiving a direct hit on his trench or be killed by splinters of the rocky surface of the Carso mountains, which could speed through the air after shelling by enemy artillery (Baxa 2010, 20). In the Italian letteratura di guerra, the most dreaded types of death were by accident, succumbing to illness, being executed by a firing squad or being killed by a random ricochet or aerial bomb behind the front. Take for example the relatively obscure, posthumously published anthology Ali $e$ alati (1918) by the Futurist artist and fighter pilot Rodolfo Fumagalli, who perished in November 1917 in the skies over the Asiago Plateau. In it, we find the following description of the violent death of a pilot called Pegoud: 'In war he had to die the beautiful death, machine-gunned after having shot down six enemy aircraft, struck in the wings that he never betrayed, and which never betrayed him' (Fumagalli 1919, 112).

Contrastingly, Fumagalli laments the death of the pilot Andrea, who dies during a training flight, as lacking the grace and aesthetic quality that only a 'beautiful death' in battle can bestow upon a fallen soldier:

He who dreamed of the fourth medal or the beautiful death in the good fight; he who smiled this morning, whom this same evening I had to meet, who waited for days for his mother's visit. Andrea, Andrea fell, he died. $(1919,168)$

By dying in an accident, instead of going down 'in a good fight' like Pegoud, the crucial narrative-aesthetic quality of Andrea's demise was significantly diminished. In other words, his death was less of a heroic tale than it could have been if he had, as the pilot Pegoud supposedly did, shot down six enemy aircraft. Hence, it is no wonder that, for himself, Fumagalli (1919) wished 'the bullet in the forehead. The beautiful death in the fight' (281). On the other hand, being killed by long-range shelling in the military hinterland appears as the most shocking, tragic and narratively memorable aspect of a soldier's death described in Antonio Pier Giovanni's novel Fante-fango-fama (1927, 93): 'A lively sense of dismay had captured them. What! Do you die so far from the enemy, without fighting, without saying the last word? A companion was lost: what could happen to others?'

The 'lively sense of dismay' expressed by Giovanni becomes comprehensible if we consider that, in the letteratura di guerra, dying behind the front lines is tantamount to dying 
by accident or through illness: these deaths could not, usually, be considered beautiful as they did not result in heroically narratable, symbolic accounts of exemplary patriotic behaviour in the face of the enemy. A similar fear of dying in an aerial bombardment, likened to a firing squad, behind the front rather than on the battlefield, is expressed in G.A. Borgese's novel Rubè (1921) by the main character, the eponymous Filippo Rubè:

You are so unprepared, your spirits are so well-tempered and at ease, when down from above comes a flash with the authority of a supreme punishment. I know why people fight and suffer, but it makes me shudder to think of those poor fellows who feel their blood run cold and their nerves go to ruin, without any notion of what it's all about. It's horrible. (Borgese 1923, 46-7)

Another spiritual fear of sudden death that was widely prevalent among religious soldiers was expressed by Lorenzo Viani in his prize-winning novel Ritorno alla patria (1928), in which soldiers are described as dreading the thought of dying without receiving the last rites, meaning not adhering to the Catholic Ars Moriendi, the 'art of dying well' (329). Although this fate could in theory be avoided whilst languishing in a field hospital, dying from illness was nonetheless considered a highly undignified end for a soldier. Thus, Benito Mussolini noted in his published war diary that 'before I die in a cholera hospital, I for my part prefer to be torn into a hundred pieces by a 305[mm] projectile' (1923, 201). It is important to add that - naturally - there were exceptions to the rule, awarded to high-ranking officers such as General Antonio Chinotto, whose 'beautiful death' from gastric cancer whilst in the middle of the Sixth Battle of the Isonzo was reported on the front page of the Corriere della Sera on 27 August 1916:

Always sick, unable to eat, he lived in the days of battle by nutrient injections, being carried in an armchair onto the line of fire. Having achieved victory, he was transported in a very serious condition to the quarantine hospital of Udine. The director, colonel Zibetti, brought him a flag that the general kissed frantically, weeping and saying: 'My homeland, I cannot give you anything anymore!' Knowing he had to die, he wanted to be wrapped in the tricolour. All the authorities were at his bedside for his last agonies. An impressive funeral is now being prepared for him. (Corriere della Sera 1916, 1)

Still, the by far most desired way to die described in the letteratura di guerra was by bullet, while attacking enemy positions. Hence, the prototypical fascist 'Aldo Franci' in Adolfo Baiocchi's novel Generazioni $(1930,236)$ searched (yet did not find) la bella fine in open battle because it was only on the field of battle that, as the veteran Leopoldo Passeri claimed in his novel Il vallone della morte $(1934,232)$, 'death is worthy of a man'. Indeed, as the prize-winning author Riccardo Bacchelli concluded in his novel Oggi, Domani E Mai (1932, 422), the 'good death' is a soldier's death in battle (described as 'the great school') and could only be fully understood by men and, strictly speaking, really only by fellow soldiers or veterans.

\section{The iconography of a beautiful death in the letteratura di guerra}

Commonly in the letteratura di guerra, the 'good death' was desired and imagined to be a quick, violent one, an idea widely disseminated throughout Italy's armed forces, and of which the best indicator is a popular trench tune that was sung by ordinary soldiers and preserved by the veteran Fascist cultural functionary and author Arturo Marpicati in his 'psychological study' of the nation's militarised proletariat, published in 1934: 
'And then one day, if the enemy bullet ( piombo) should fully hit my heart, it will not be a ferocious death, it will be a death that heroes have' (72).

An additional crucial element for a beautiful death was described by Benito Mussolini in his above-mentioned war diary, in which the future Duce went to great lengths to narratively immortalise the 'upright', beautiful death of a stern and dutiful officer:

As soon as the fight had begun, Villani, standing upright, commanding the advance of the groups, was wounded by a gunshot. He did not pay attention. Shortly thereafter, the explosion of a grenade knocked him down. He had scarcely time to shout: 'Bersaglieri the seventh company forward! Right! Spread to the right! Viva l'Italia!' Then he died. $(1923,30)$

Dying 'beautifully' in an upright pose with eyes fixed on the enemy, rousing words to the troops (or, variably, a final tactical order) and shouting a last, heroic 'Viva l'Italia' is frequently advertised in the letteratura di guerra as the most desirable end a man could seek and find as a conclusion to his earthly life. Thus, the Roman veteran Riccardo Pizzicaria narrates the following bella morte in his short story collection Fucili e fede $(1935,36)$ : 'He just wanted to get on his feet, so that certain death which he consciously faced would find him [standing] upright like the heroes of history and of legend. And he fell like them'. In another episode, simply entitled Morire ('To die'), an adolescent protagonist proclaims that death was 'nothing and it could also be beautiful, at 20 years old in the shadow of the flag' (Pizzicaria 1935, 33). Indeed there is, as we learn in Pizzicaria's one-act dramatic play Castagnevizza $(1930,176)$, something far 'more horrible' than a 'good death' - namely, 'the loss of honour' in capitulation. The same idea of an undefeated bella morte was also conveyed in Cesco Tomaselli's narration of the death on Mount Kamno in Slovenia of lieutenant colonel Maurizio Piscicelli from Naples, who preferred death to potential surrender:

At the head of one of these nuclei of resistance is the lieutenant colonel Maruzio Piscicelli commanding the third battalion of the 147th infantry, who on the positions of Kamno stands up with his men to the overwhelming forces, is requested to surrender, refuses indignantly, and is shot to death, reclining on a machine gun after having launched a final hurrah to Italy. $(1931,40)$

In a similar way, Tomasselli $(1931,157)$ recounts the end of cavalry captain Ettore Lajolo, of the $4^{\circ}$ squadrone di Genova, whose death was exemplarily chivalric and thereby 'beautiful': "Boys," he shouts, "the 4th squadron does not retreat," and saying this, he locks his helmet and spurs his horse, lifting his sabre: those words were his last. A moment later, "the beautiful knight" is discharged through death.'

Indeed, even if a military operation may have seemed futile or downright foolish, a 'beautiful death' could still crown an endeavour with glory, as we learn in the short story Mariuta included in Umberto Mancuso's Novelle beffarde (1927, 63), in which we read that the protagonist 'died at the head of a group of volunteers, riddled by machinegun bullets, during the most insane business. He shouted, dying, "I'm from Trieste. Long live Trieste of Italy!"' Similarly, in a diary entry dated 24 February 1916, Mussolini (1923) relates the following exemplary bella morte of an unnamed sergeant on the Carso:

Major Tentori also tells me the heroic end of a sergeant who fell from a belly shot, shouting with the last of his strength, 'It seems to me that I am dying, but I like dying for Italy, long live Italy'. (110-11) 
However militarily inconsequential and pointless, in the logic of la bella morte, only this last patriotic declaration differentiates and individualises the dead soldier from the nameless mass death suffered around him and transforms the fallen into a heroic figure and venerated object of nationalist propaganda.

\section{Beautiful corpses}

Whilst incorporating a series of characteristic elements, such as falling in an upright pose and uttering a last patriotic evocation, created the classical image of a 'beautiful death' in battle, the ideal death could take yet more aesthetic forms by adding circumstantial, panegyric elements to it, such as through the description of the imagined thoughts engulfing the falling soldier's mind during the final moments of his life or through the retrospective, narrative transformation of the fallen into a heroic monument to patriotic resistance and dedication. For example, in his best-selling Diario di un imboscato (1919), the journalist Attilio Frescura $(1930,385)$ records the death of a 60 -year-old volunteer named Giulio Blum, who fell at the head of his company whilst waving the tricolour, as a 'most beautiful gesture'. In his memoirs La guerra a tremila metri (1928), Ulrico Martinelli $(1996,88)$ narrates the archetypal death of the alpino Olari Pietro, who dies 'beautifully', as a 'wonderful example of sublime simplicity combined with heroic stoicism'.

Indeed, accepting death with a relaxed, almost indifferent attitude was frequently presented as another supremely beautiful way to die by the authors of letteratura di guerra. Thus, in Salvator Gotta's Pronti? Forza $(1919,41)$, the stoic march of a column of soldiers towards certain death represents an aesthetic spectacle of unrivalled delight and sensual pleasure: 'The column moved with the clamour of arms and steps and weights held on the sturdy shoulders by the leather straps. Not one cry for mother. Tragic night! Beauty without name of going to die without looking back'.

Similarly, in Carlo Pastorino's war memoirs La Prova del Fuoco (1939), we read about the death of a certain officer named Donzelli, who 'died as one dreams the heroes must die: hence, with the burning heart, with the words of glory and victory on the lips and with the eyes to the sky' (Pastorino 1989, 205). A recurring variant of the 'words of glory and victory' were patriotic songs and hymns. As contemporary reviewers pointed out, one of the most uniquely 'Italian' aspects of letteratura di guerra was the plentiful singing being done by the nation's soldiers while on the front lines (Moll 2021 forthcoming). In fact, in the Italian literature of the Great War, singing often appears as a foreboding symbol of impending death. Thus, Giorgio Maria Sangiorgio evokes the same clichéd image of trigger-happy, stoic death-seekers in $75 \mathrm{~m} / \mathrm{m}(1932,114)$, when he writes about a battalion of Arditi marching by his narrative alter ego on the way to the front and who, following their motto me ne frego ('I don't give a damn!'), 'sing and go to die'. A very similar scene was also described by the sniper Michele Campana, who remarked in his memoirs Perchè ho ucciso? $(1918,52)$ that a column of young Arditi marching directly into Austrian artillery fire singing a patriotic hymn was nothing but 'the challenge of the spirit to death'.

Similarly, during a romantic moonlit evening in 1916 during the Venetian carnival, whilst gazing onto the city's canals, the convalescing d'Annunzio (1921) saw:

three large barges being towed by a steamboat. They are full of recruits yelling and singing their way to faraway trenches. They are the Fatherland's cargo, a cargo of flesh and blood more beautiful than the fruits of the shores and islands unloaded at the Rialto bridge in deep baskets. (411-12)

Such decadent images of the happy self-offerings of brave young men attaining an alleged spiritual triumph over death represented an almost seamless continuation of philosophical, 
artistic, mythological and religious discourses that had been ingrained into Italian culture for centuries, but which were particularly prominent in the two decades leading up to the Great War, and whose narration reached its qualitative and quantitative apex in the letteratura di guerra.

Yet it was not only in life but also after a soldier's sudden death in battle that the corpse of the fallen warrior was transformed into a 'beautiful' monument to death, such as in the case of a corporal from the Brigata Como, who, as Tomaselli $(1931,293)$ recounts, was 'struck in the forehead while he was firing in the open; he was still there on his knees, with his eyes open, in a manner of such ineffable naturalness that made one think he was adoring a vision'. In a similarly euphemistic way, writing in his war memoirs La prova del fuoco (1939), Carlo Pastorino (1989) narratively transformed a dying soldier into a beautiful corpse on whose

still-unpeeled face a thick blond lint is spread, and a white hand with long, thin fingers rests on his chest. Struck in the heart, his death was instantaneous: he suffered nothing. His face is beautiful: it is the face of an innocent at rest. (45)

An image that evokes the same bliss of death can be found in Giorgio Maria Sangiorgio's $75 \mathrm{~m} / \mathrm{m}(1932,177)$, in which a fallen soldier's 'eyes were wide, his mouth halfopen and he seemed to smile, and his hands gathered on his chest over the wound, juxtaposed in prayer'. In Alfredo Panzini's Diario Sentimentale Della Guerra $(1923,136)$, we even learn that the corpse of a certain Captain Milesi was found to have resembled the image of the Saviour: 'He dies in the advance. Colonel Pistoni with great peril retrieves the corpse. (It was a pallid face with a beard clinging with blood like Christ).'

Free of any religious references and instead filled with blissful patriotic conviction, in Alessandro Tandura's spy memoirs Tre Mesi di Spionaggio Oltre Piave, Agosto-Ottobre 1918 (1934), soldiers die with a smile on their faces, confident of Italy's ultimate victory (Tandura 2005, 146). In another case, while coming upon some corpses in the rear of the Piave in 1918, and never missing a chance to transform massacre into war kitsch, the Futurist godfather Francesco Tommaso Marinetti $(1921,210)$ was bucolically reminded of 'sleeping gardeners, tired by excessive hoeing'. Yet such romanticising images of blissful demise were not merely confined to the pages of the letteratura di guerra, but could be found in genre-related contemporary accounts of private and public mourning. As Oliver Janz $(2009,93)$ has lucidly argued in his analysis of private commemorative booklets published by grieving Italian families during and after the Great War, in the memory of their fallen loved sons, brothers and fathers, the inviolacy of the soldier's body and the subsequent 'beauty' of the corpse were of primary psychological and religious importance to the bereaved - a concern that is frequently reflected in the images of la bella morte presented in the genre products of letteratura di guerra.

Hence, in Salvator Gotta's children's war novel Piccolo Alpino (1930), the corpse of a fallen soldier emanates an (an-) aesthetic, completely sanitised, tangible aura of beauty and sacredness, signalling to his youthful audience the alleged desirability of a hero's death in battle:

A dead soldier! He was really dead! Died for the Fatherland! Giacomino felt a thrill in his veins, almost as if he were close to something sacred, beautiful. He was the first dead man he saw, which he touched; but he did not fear him at all. He was a fallen soldier performing the purest and highest duty! He was a hero! Just before, he had spoken! How sweet the death of heroes is! (84) 
Whilst the fallen alpino in Gotta's story became a 'sacred, beautiful' monument to death that could be physically touched and felt, the presence of a dead soldier in other instances could still serve a useful, whilst undoubtedly morbid, military purpose. According to the ex-Ardito Ferruccio Vecchi (1923), the mystical-martial spirit (L'Ardire - 'The Dare') and feared reputation of the elite corps of the Arditi was still visible in the face of one the unit's fallen members - so much so that it could frighten Austrian soldiers into panicked retreat:

Moreover, the Ardire emanates even after the death of those who manifested it tenaciously: two Austrians, having, I remember, seen an Ardito killed, soaked with blood, resting on the right side in a dreamy position, fled after the first trembling examining glance, fearing that he would jump up again! ... It was Ferruccio Amato from Forlì; he still smelled of dust ... he looked like a nice, unexploded bullet which, pretending to sleep, still watched with his pointed, dark, dangerous face. (33)

To be truly bello, a corpse had to be fresh, as the author Alfredo Panzini $(1923,37)$ noted in his Diario Sentimentale di guerra, in which he also wrote that the first face of death in war' was always beautiful until the head of the fallen was transformed into a mere skull among skulls. Keeping the corpse of the fallen aesthetically appealing was, in this sense, a morbid yet nonetheless essential act of memorialisation. However, especially after air battles and plane crashes, the chances of recovering a relatively unviolated body were exceedingly slim. As d'Annunzio (1921) reports with an unusual degree of realism in his war memoir Notturno, the recovered corpse of his fellow pilot Giuseppe Miraglia, who had crashed into the Venetian Lagoon testing a new prototype plane in December 1915, first resembled a sleeping, blessed, 'ennobled' monk, until it finally turned into a decomposing, black-yellow-coloured mass that was nonetheless kept as 'fresh' and life-like as possible by means of repeated chemical injections applied by watchful army doctors $(58,69,74)$.

By contrast, the unrecovered corpse of the Italian pilot Roberto Prunas, whose plane uncannily exploded at almost precisely the same spot as Miraglia's in April 1916, became, in d'Annunzio's imagination, 'swollen and whitish', dangling miserably against a barrage of sea mines (d'Annunzio 1921, 414; Winwar 1956, 278). When a body was recovered, speeches delivered in front of the coffin, glorifying the beautiful manner of the fallen's death, were an integral part of posthumous memorialisation. Hence, as d'Annunzio explained in a eulogy for the French pilot Jean Rouher, who died on 15 August 1916 during a raid on the town of Muggia near Trieste and whose corpse was laid to rest two days later in a solemn funeral on 17 August at the Ospedale Sant'Anna in Venice, 'a beautiful death' was 'the supreme crown of combat' that 'no other price, no other value' could equal. Rouher, d'Annunzio (1916) continued in his usual dark-romantic pathos, had

died in the summit of the day: he fell into the sea as into the light, as a daytime meteor: he striped the purest Italian sky with his noble blood. Just as he was struck, he remains engraved in our memory, bent on the edge of the cockpit to observe the effect of the bomb that he had put on the intended target with his masterful hand. (2)

In his funeral speech, d'Annunzio, to whom death 'appeared but as the eternal form of my perfection' $(1921,214)$, thus faithfully reproduced all the elements of what we have come to recognise as a 'beautiful death' in the Italian myth of the Great War: killed at noon, whilst utterly transfixed by his destructive work, Jean Rouher could, in the words of the war veteran Giosuè Borsi $(1915,209)$, 'not better have crowned his life'. 


\section{Class, unit, rank and the shades of falling for Italy}

Although ordinary soldiers could sometimes attain memorialisation as beautiful corpses, there is a noticeable quantitative as well as qualitative difference in the death experienced by the mass of ordinary privates vis-à-vis that of their superiors. Whilst the authors of letteratura di guerra, who usually held officer ranks themselves (Mondini 2014, 315-16), described the bella morte of their fellow officers and that of members of elite formations like the Arditi or Alpini with much narrative detail (usually including their names, hometowns/garrisons, units and ranks), gusto and stylistic effort, the death of the mass of nameless fanti was rarely commemorated with similar acts of individualisation. In fact, as Cesco Tomaselli admits in Gli 'ultimi' di Caporetto (1931), more often than not, their end was all but a beautiful one:

The roll call was made in Bergogna. Three hundred men replied; it was all that remained of three companies. Most of them were left on Monte Stol, lying on the rocks, in those strange and clumsy positions that are typical of death, which rarely respects aesthetics. (274)

Carlo Pastorino $(1989,174)$ gave a similar description of the gruesome death of a group of military sappers from the Marche region, who 'fell on top of each other, a heap of broken limbs, of bloody flesh, of eyes that were gradually extinguished'. Portraying a different battlefield, but evoking almost the same images as Pastorino, Riccardo Pizzicaria (1935) portrays the morbid aftermath of trench battle in Fucili e Fede as follows:

In that light, in an opaque light of sadness, there are empty bodies that lie on the parapet and in the bottom of the trench, corpses of our soldiers and those of Austria, being thrown into each other in violent assaults, in death united and composed in the same face of human piety. (15)

Indeed, only seldom do we encounter the halo of la bella morte in the face of ordinary infantrymen, such as in the following description of the death of two peasants in G.M. Sangiorgio's novel $75 \mathrm{~m} / \mathrm{m}$ :

I saw the two fallen in the evening, as they laid them on stretchers. One had a bandaged head and a blood stain on the left temple, the whiteness of the bandage stained with vermilion: the pale faces, full of purple shadows on the closed eyelids, so refined by death and cold, looked like the faces of angels. They were two peasants.

$(1932,197)$

Yet, even in this exceptional instance, and in marked contrast to the hyper-detailed, highly personalised description of officers' deaths, the two fallen contadini remain essentially nameless objects of Sangiorgio's romanticisation of the fighting spirit and sacrifice offered by the peasantry to the nation's cause. Indeed, at another point in $75 \mathrm{~m} / \mathrm{m}$, his alter ego Capella witnesses the death of a regular fante in the following awkward, much more conventional, sober and pragmatic way, 'A soldier falls on me, tumbles between the stones. He died amongst the stones. He is dead' (Sangiorgio 1932, 193).

Whilst the mass of common soldiers populating the pages of the letteratura di guerra thus died an undignified, unaesthetic and unremarkable death, the violent demise of members of the officer corps, the Alpini or the Arditi formations was often imbued with idiosyncratic meaning that elevated la bella morte (or the prospect thereof) into an apotheotic act that had the potential to purify, sanctify and reinvigorate those soldiers 
who survived the liminal experience of battle. This radical difference in the representation of dying in battle narratively reproduced the highly stratified nature of the Italian army and reflected the genre's above-mentioned nature as the literary product of the nation's officer class (Mondini 2014, 314). As Marco Mondini (2014, 312) has pointed out, except as a 'psychological' and 'anthropological' object of study, 'in general ... the soldier's view remained "irrelevant”".

However, instead of being in any way subversive in its contrasting descriptions of death in battle, the letteratura di guerra actually became prototypical for the production of a new, realistic as well as spiritual kind of national literature. This combined the highbrow idealisation of an 'ethical' (sacrificial) death that had been an important topic of prewar, d'Annunzian literature with the folkloristic idealisation of a morally uncorrupted, fertile, brave and stoic peasantry that became the favourite subject of the ruralist Strapaese movement, which could count veteran-authors of war literature (and even earlier interventionist books) such as Ardengo Soffici, Corrado Alvaro and Curzio Malaparte among its ranks (Ben-Ghiat 2011, 49-50).

Indeed, only the simultaneous celebration of the bella morte of members of the officer corps and the elite Arditi formations and the naturalistic depiction of the suffering of the common people created the specific pathos of national sacrifice that became the emotional soundtrack of the Fascist commemoration of the Great War and which, finally, distinguished the letteratura di guerra from other kinds of war literature, such as the British, in which irony served to shatter the myth of the beauty of battle and devalued prewar class distinctions between officers and privates (Fussell 2000, 29).

\section{Conclusion}

Before the outbreak of the Great War, the myth of beautiful death in battle had been intensely cultivated in the nationalist intellectual milieu that became the vanguard of the interventionist camp between August 1914 and May 1915 (Ventrone 2003). As authors such as d'Annunzio, Soffici and Marinetti subsequently turned their war experiences into letteratura di guerra, the already well-established myth of la bella morte was applied to the battlefields of the Great War, creating an iconography of the fallen soldier that became surprisingly standardised and shared by members of all branches of the Italian armed forces.

Crucially, there were no noticeable distinctions between fictional and non-fictional libri di guerra, nor between authors with combat experience and those without, pointing to the universality of the notion of la bella morte amongst varied literary agents throughout Italian society and its organic rootedness in cultural discourses that transcended the notorious division between front and home front. Indeed, whilst the vision of a beautiful death in battle was usually reserved for officers and members of elite units, the letteratura di guerra also depicted the suffering of the front-line troops in a highly realistic manner. These ambivalent descriptions of the highly individualised 'hero's death' of officers and the anonymous mass death of front line troops finally made the Italian literature of the Great War central to the Fascist literary canon, in which sentimental aestheticisation and frank realism became the principal ways of cultural expression.

Acknowledgements. I would like to thank the anonymous reviewers who provided valuable feedback for this article. The basis of this article has been a chapter of my doctoral dissertation, which I completed at the University of Cambridge in 2020. I would like to thank my doctoral supervisors, Prof. John F. Pollard (Cambridge) and Dr Hannah Malone (Berlin), for their invaluable advice and encouragement throughout my PhD. I would also like to thank Prof. Robert S.C. Gordon (Cambridge) for his comments on the doctoral dissertation and specifically the chapter this article was originally based on. Finally, I would like to thank the organisers of the ASMI Postgraduate Virtual Symposium 2020, where I presented part of my research on the topic of la bella morte in the letteratura di guerra and received valuable comments from participants. 
Competing interests. The author declares none.

\section{Notes}

1. On the social structure of the Royal Italian Army, see Gibelli 1998. 87-8.

2. One of the main theorists of Italian realism during the Fascist period, the influential literary critic Arnaldo Bocelli $(1935,427)$, praised the letteratura di guerra's authors for their frank, precise and non-ornamental language.

\section{References}

Audoin-Rouzeau, S. and A. Becker. 2002. 14-18: Understanding the Great War. New York: Hill and Wang. Bacchelli, U. 1932. Oggi, domani e mai. Milan: Treves.

Baiocchi, A. 1930. Generazioni. Milan: Alpes.

Bassi, M. 1915.'Attraverso la Serbia guerriera, La bella morte'. La Stampa, 20 May, 3.

Baxa, P. 2010. Roads and Ruins, The Symbolic Landscape of Fascist Rome. Toronto: University of Toronto Press. Ben-Ghiat, R. 2011. Fascist Modernities, Italy, 1922-1945. Berkeley, CA: University of California Press.

Bocelli, A. 1935. 'Scrittori d'oggi'. Nuova Antologia 7: 427-33.

Borgese, G.A. 1923. Rubè. New York: Harcourt, Brace and Company.

Borsi, G. 1915. Lettere dal fronte (Agosto-Novembre 1915). Turin: Libreria Editrice Internazionale.

Bracco, B. 2012. La Patria Ferita, I corpi dei Soldati italiani e la Grande guerra. Florence: Giunti Editore S.p.A.

Caffarena, F. 2013. 'Armed with Pen and Paper: Soldiers and Writing between Story, Memory and the History of the Great War'. In The Great War in Italy, Representation and Interpretation, edited by P. Piredda, 167-77. Leicester: Troubador Publishing.

Campana, M. 1918. Perchè ho ucciso? Florence: Libreria della Voce.

Corriere della Sera. 1916. 'La bella morte del gen. Chinotto, Spira avvolto nella bandiera'. 27 August, 1.

d'Annunzio, G. 1921. Notturno. Milan: Treves.

d'Annunzio, G. 1897. The Triumph of Death. trans. A. Hornblow. New York: George H. Richmond \& Co.

de Roberto, F. 1917. La messa di nozze, Un sogno - La bella morte. Milan: Fratelli Treves, Editori.

Domenichelli, M. 2004. 'Voilà la belle mort': The crisis of the aristocracy in Troilus and Cressida'. In Shakespeare, Italy, and Intertextuality, edited by M. Marrapodi, 59-72. Manchester and New York: Manchester University Press.

Edward, C. 2007. Death in Rome. New Haven: Yale University Press.

Frescura, A. 1930. Diario di un imboscato. Bologna: Licinio Cappelli.

Fumagalli, R. 1919. Ali e alati. Milan: L'Eroica.

Fussell, P. 2000. The Great War and Modern Memory. Oxford: Oxford University Press.

Gibelli, A. 1998. La grande guerra degli italiani, 1915-1918, Prefazione di Giovanni Belardelli. Milan: RCS Libri S.p.A.

Goebel, S. 2007. The Great War and Medieval Memory: War, Remembrance and Medievalism in Britain and Germany, 19141940. Cambridge: Cambridge University Press.

Gotta, S. 1919. Pronti? Forza! Milan: Sonzogno.

Gotta, S. 1930. Piccolo alpino. Romanzo. Milan: A. Mondadori.

Isnenghi, M. 1973. Il mito della grande guerra. Bari: Editori Laterza.

Janz, O. 2009. Das symbolische Kapital der Trauer: Nation, Religion und Familie im italienischen Gefallenenkult des Ersten Weltkriegs. Tübingen: Max Niemeyer Verlag.

Jox, R., E. Montaguti, M. Picozzi and E. Zwick. 2018. "From the Concept of "Good Death" in the Ancient World to the Modern Concept of "Euthanasia”. Medicina Historia 2: 104-108.

Mancuso, U. 1927. Novelle beffarde: Illustrate dai pittori Terzi, Camerini, Onorato. Rome: Stock Editore.

Marinetti, F.T. 1921. L'alcova d'acciaio, Romanzo Vissuto. Milan: Casa Editrice Vitagliano.

Marpicati, A. 1934. La proletaria. Saggi sulla psicologia delle masse. Bologna: Licinio Cappelli Editore.

Martinelli, U. 1996. La guerra a tremila metri, dallo Stelvio al Gavia. Chiari: Nordpress Edizioni.

Moll, C. Forthcoming 2021. 'Producing, Consuming and Negotiating Literature of the Great War in the Italian Cultural Market, 1915-1935’. Publishing History.

Mondini, M. 2014. 'The Construction of a Masculine Warrior Ideal in the Italian Narratives of the First World War, 1915-68'. Contemporary European History 23: 307-27.

Mosse, G.L. 1990. Fallen Soldiers, Reshaping the Memory of the World Wars. New York: Oxford University Press.

Mussolini, B. 1923. Il mio diario di guerra (1915-1917). Milan: Casa Editrice 'Imperia'.

Oriani, A. 1924. La rivolta ideale; Prefazione di Benito Mussolini. Bologna: Licinio Cappelli Editore.

Panzini, A. 1923. Diario sentimentale della guerra. Rome: Mondadori. 
Passeri, L. 1934. Il vallone della morte. Brescia: Vanini.

Pastorino, C. 1989. La mia guerra: La prova del fuoco, la prova della fame. ed. Francesco De Nicola. Genoa: Casa Editrice Marietti S.p.A.

Pier Giovanni, A. 1927. Fante- fango- fama. Romanzo con prefazione del Duca della Vittoria. Parma: Stamperia Bodoniana.

Pizzicaria, R. 1930. Razzo Rosso, tre atti grigio-verdi. Castagnevizza: bozzetto drammatico in un atto. Florence: Bemporad.

Pizzicaria, R. 1935. Fucili e fede. Rome: Ed. Orizzonti.

Rita Gaza, C. 2014. Morire, uccidere: L'essenza della guerra. Milan: FrancoAngeli.

Sangiorgi, G.M. 1932. 75 m/m. Romanzo di guerra. Milan: Agnelli.

Shinners, J., ed. 1997. Medieval Popular Religion, 1000-1500. Peterborough, Ontario: Broadview Press.

Il Sofista, G. 1960. 'Decadenza borghese'. In La cultura italiana del '900 attraverso le riviste, Volume primo 'Leonardo' 'Hermes' 'Il Regno', edited by D. Frigessi, 129-31. Turin: Giulio Einaudi Editore.

Tandura, A. 2005. Tre mesi di spionaggio oltre Piave, Agosto-Ottobre 1918, Prefazione di S.E. Giovanni Giuriati. Vittorio Veneto: Kellermann Editore.

Todero, F. 1999. Pagine della Grande Guerra, Scirtori in grigioverde. Milan: Gruppo Ugo Mursia Editore.

Tomaselli, C. 1931. Gli 'ultimi' di Caporetto. Racconti del tempo dell'invasione. Milan: Treves.

Vecchi, F. 1923. La tragedia del mio ardire: romanzo. Milan: Arti Grafiche Italiane.

Ventrone, A. 2003. La seduzione totalitaria: guerra, modernità, violenza politica (1914-1918). Rome: Donzelli Editore.

Viani, L. 1928. Ritorno alla patria. Milan: Alpes.

Wilcox, W. 2018. Morale and the Italian Army during the First World War. Cambridge: Cambridge University Press.

Winter, J. 1998. Sites of Memory, Sites of Mourning, The Great War in European Cultural History. Cambridge: Cambridge University Press.

Winwar, F. 1956. Wingless Victory: A Biography of Gabriele D’Annunzio and Eleonora Duse. New York: Harper.

Dr Carlo Moll is a visiting scholar at the University of Cambridge, from where he received his PhD in History in 2020 with a thesis on counter-culture and hegemony in Italian nationalism and Fascism. His past research has focused on the Italian letteratura di guerra, elitism and Florentine modernism.

\section{Italian summary}

Attraverso la lettura comparata della letteratura di guerra pubblicata fra il 1915 e il 1940, verrà mostrato come sia tra i veterani del primo conflitto mondiale che tra gli scrittori civili esistesse un'immagine standardizzata dell'uomo caduto in modo 'bello' in combattimento che prevedeva componenti specifiche relative al luogo, al tempo, ai gesti finali e alle ultime invocazioni e che mirava a rendere la morte in battaglia più appetibile al pubblico italiano, sia da un punto di vista militare che culturale. Allo stesso tempo, la letteratura di guerra presentava anche descrizioni naturalistiche della morte di masse anonime di soldati comuni e generava così un pathos di bellezza e sofferenza che ha reso la letteratura italiana della Grande Guerra un prototipo per un nuovo tipo di realismo spirituale divenuto uno dei capisaldi dell'espressione culturale nell'Italia fascista.

Cite this article: Moll C (2022). The idea of a beautiful death in Italian literature of the Great War. Modern Italy 27, 91-103. https://doi.org/10.1017/mit.2021.50 